\title{
„Államosított tértermelés” a kiszorítottak perspektívájából egy dzsentrifikálódó városrészben
}

\section{The "nationalised production of space" from the perspective of displaced people in an urban district undergoing gentrification}

\author{
TIMÁR JUDIT
}

TIMÁR Judit: tudományos fömunkatárs, Közgazdaság- és Regionális Tudományi Kutatóközpont, Regionális Kutatások Intézete; 5600 Békéscsaba Szabó D. u. 42.; timar.judit@krtk.mta.hu; https://orcid.org/0000-0002-5275-6905

KULCSSZAVAK: városrehabilitáció; dzsentrifikáció; térbeli kiszorítás; államosított tértermelés

ABSZTRAKT: Tanulmányom célja az, hogy a jelenlegi magyarországi városrehabilitáció/ dzsentrifikáció által okozott társadalmi-térbeli kiszorítás tanulmányozásával hozzájáruljak a társadalmi viszonyok, elsősorban az állam és a kiszorításnak kitett csoportok viszonyának megértéséhez. Ennek érdekében a dzsentrifikációt, illetve kiszorítást a lefebvre-i felfogásban vett „tértermelésként” értelmezem, e folyamatokat a tőke globális újratermelése, valamint a globális urbanizmus szerves részének tekintem, s egy győri esettanulmány segítségével vizsgálom. Az alkalmazott szemléletben a dzsentrifikáció (városrehabilitáció) hatására átalakuló tér sokkal szélesebb értelmezést kap magánál a dzsentrifikálódó városrésznél, részévé válnak a kiszorítottak megélt terei is. E tértermelés megismerésének érdekében az aktuálisan zajló dzsentrifikáció tanulmányozása mellett fontos szerepet kap a tanulmányban egy korábbi termelési módban (az államszocializmusban) kezdődött, slumosodásként leírható előzmények számbavétele, a kutatott terület korábbi és mai lakói megélt tereinek az önkormányzat elgondolt terével összevetett vizsgálata.

A tanulmányban Lefebvre térelméletének itt vázolt kérdések megértését segítő rövid áttekintéséből kiindulva, majd a Győr-Újváros dzsentrifikációját dokumentumok, szakértői és lakossági interjúk segítségével elemző empirikus vizsgálat eredményeinek bemutatásával jutok el a fó állításhoz. A mellett érvelek, hogy a városrehabilitáció/dzsentrifikáció által kiszorítottak és az állam viszonya perspektívájából nézve - a Győrben is érzékelhető új gazdasági, államszervezési kontextusban -, a mai Magyarországon egyfajta „államosított tértermelésről” beszélhetünk. Ennek a fajta tértermelésnek a során a marginalizált társadalmi csoportok „dupla kontrollt” élnek meg. Az önkormányzattól való függőségük egyben a központi államtól való függőséget is jelent. A városrehabilitáció során a helyi, s indirekt módon a központi állam újratermeli azokat a társadalmi viszonyokat, amelyek - Castel „szociális kohézió zónáit” leíró koncepciójának terminológiájával kifejezve - a „segélyezés” zónájában tartják a térbeli kiszorításnak kitett embereket.

Judit TIMÁR: senior research fellow; Institute for Regional Studies, Centre for Economic and Regional Studies; Szabó D. u. 42., H-5600 Békéscsaba, Hungary; timar.judit@krtk.mta.hu; https:// orcid.org/0000-0002-5275-6905

KEYWORDS: urban rehabilitation; gentrification; displacement; nationalised production of space

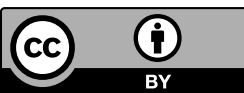


ABSTRACT: The paper aims to contribute to a better understanding of social relations, primarily the relationship between the state and those exposed to displacement, through the study of sociospatial displacement caused by current urban rehabilitation/gentrification in Hungary. To this end, it interprets gentrification and displacement as the production of space in accordance with Lefebvre's theory (1991). It considers these processes as an integral part of the global reproduction of capital and global urbanism and examines them through a case study on Györ. According to the perspective applied, the space transformed by gentrification (urban rehabilitation) means more than just neighbourhoods being gentrified. It also includes the lived (concrete) spaces of the displaced. In order to understand this production of space, a two-pronged approach is essential: An investigation of recent gentrification, taking stock of past developments, which are best described as socialist disinvestment, must be complemented by a comparison of the lived spaces of the former and present inhabitants with the conceived space of local government.

After a brief theoretical overview of Lefebvre's theory of space to better understand the issues outlined in the study, the results of an empirical study on gentrification in Györ-Ujváros are presented by means of documents and interviews with experts and the population. In essence, it is argued that in a new economic and state administrative context, which also influences Gyorr, production of space in Hungary has been "nationalised" from the perspective of the relationship between those displaced by urban rehabilitation/gentrification and the state. The marginalised social groups experience "double control" in this type of production of space. Their dependence on the local government also means dependence on the central state. Local governments and the central state the latter partly indirectly through the former and partly directly - reproduce social conditions in the course of urban rehabilitation that keep those exposed to displacement in the zone of welfare recipients, as Castel (1993) suggested in his concept describing "the zones of social cohesion".

\section{Bevezetés}

„Az otthonról és szomszédságból történő kiszorítás megrázó tapasztalat lehet. Legrosszabb esetben hajléktalansághoz vezet, legjobb esetben gyengíti a közösségi érzést. A közpolitikának - általános megegyezés szerint - minimalizálnia kellene a kiszorítást. Mégis, úgy tűnik, a különböző közpolitikák, különösen a dzsentrifikációban érintettek, elősegítik azt." (Marcuse 1985: 931.)

Marcuse 1985-ben megfogalmazott kritikája után közel két évtizeddel Smith (2002) már messzebbre ment annál, hogy a dzsentrifikációval járó társadalmi-térbeli egyenlőtlenségek, konfliktusok kezelését kérje számon a helyi államtól. Arra világított rá, hogy az időközben a piac teljes értékü szereplőjévé vált neoliberális állam a globális tőke- és kultúraáramlás körforgásába kapcsolódó dzsentrifikációt általánosan alkalmazott városfejlesztési stratégiává tette. Ezt az állítást a több mint egy tucat nyugat- és kelet-közép-európai kis- és középváros kétezres évek elején zajló revitalizációs programjaiba bepillantást engedő kutatásunk tapasztalatai is igazolni látszottak (Nagy, Timár 2008, 2012). Ez a kritizált stratégia egybeszövi a globális pénzpiacokat, az ingatlanfejlesztőket, helyi kereskedőket stb. az önkormányzatokkal, melyek a kedvező társadalmi eredményeket már a piactól és nem annak szabályozásától remélik. A városfelújítás legfeljebb a retorika szintjén zajlik az egész „városért” (Timár, Nagy 2007; Boros et al. 2008; Nagy, Nagy 2019), az annak nevében cselekvő döntéshozók a város társadalmának diszkurzív teréből is kiszorítják az osztályvagy etnikai hovatartozás miatt a társadalom perifériájára szorultakat. 
A jelentős gazdasági potenciállal bíró Regensburgban például a helyi döntéshozók a neoliberális várospolitikával irányított városmegújítást a közpénzek és a magántőke együttmüködése során felszínre kerülő új konfliktusok ellenére is kifejezetten sikeresnek értékelték, annak „,társadalmi elfogadottságára”, , , résztvevők érdekeinek konszenzuson nyugvó beintegrálására" hivatkozva. Az általuk megnevezett „érdekeltek” (önkormányzat, befektetők, kisvállalkozók és érdekvédelmi szervezeteik, ingatlantulajdonosok, bankok és helyi média) stratégiai szövetsége valóban jól működött. Kutatásunk során azonban az „érdekeltek” körébe egyszer sem sorolták be a revitalizált városrészekből lakókként és/vagy fogyasztókként kiszoruló alacsony társadalmi státuszú regensburgiakat, a bevándorlókat (Nagy, Timár 2008).

Ugyanekkor egy jóval kisebb és számottevően kevesebb fejlesztési forrással rendelkező városban, Veszprémben is azt találtuk, hogy az ezredforduló küszöbén a helyi városmegújítási/városrehabilitációs programban, mint számos más magyarországi városban is (Kovács 2005; Csanádi et al. 2007; Egedy 2007; Somogyi et al. 2007; Czirfusz et al. 2015), az „irányítást” a magántőke vette át (Timár, Nagy 2007). A várospolitika - részben forráshiányra hivatkozva - szabad teret engedett a tőke térformáló szerepe érvényesülésének s alapvetően e tőke érdekeinek szolgálatába állt. A városfelújítás célja deklaráltan is a dzsentrifikáció lett. Az ennek következményeként kibontakozó, középvárosi viszonylatban nagyszabású dzsentrifikációt azonban több mint kétszáz hátrányos helyzetű - szinte kivétel nélkül roma - család önkormányzati programként végrehajtott kitelepítése kísérte. Az önkormányzat nem is próbált az ott lakók legalább részbeni helyben tartását eredményező „szociális rehabilitációt” szervezni. Sem a szociális irodát - illetve ellátó intézményeket -, sem a kiköltöztetni tervezett lakókat nem vonták be az előkészítési folyamatba (Timár, Nagy 2007).

Egy évtizeddel később olyan városban (Győrben) volt módunk az állam szerepét - többek között ${ }^{1}$ - a város központi részén található Újvárosban zajló dzsentrifikációhoz kötődő kiszorításban kutatni, amely hazai viszonylatban különösen erős gazdasági potenciállal és innovációs adottságokkal rendelkezik (Rechnitzer et al. 2004). Ez a város ráadásul már egy időközben megváltozott politikai gazdasági térben, nemzet-, sőt szupranacionális (EU) állami közremüködéssel szociális rehabilitációt is megvalósított.

E tanulmányban - a jelzett korábbi kutatások és irodalmak ismeretében - a győri empirikus kutatás néhány új eredményét foglalom össze. Kevésbé szánom azonban e konkrét városra szorítkozó elemzésnek, sokkal inkább egy olyan esettanulmánynak, aminek a segítségével a neoliberális kapitalizmus tértermelésben megtestesülő társadalmi viszonyairól olyan kontextusban tudhatunk meg többet, melyben a dzsentrifikáció és a térbeli kiszorítás egy immáron centralizált állam (Pálné Kovács 2019) irányításával zajlik, de gyökerei az államszocializmusig nyúlnak vissza. A tanulmány reményeim szerint azért mutathat túl a győri eseten, mert a dzsentrifikációt s az ehhez kapcsolódó társadalmi-térbeli kiszorítást a le- 
febvre-i (1991) felfogásban vett tértermelésként értelmezve, azokat a tőke globális újratermelési folyamata (Smith 1996), valamint a globális urbanizmus (Smith 2002) szerves részének tekintem. A helyi szereplők sajátos konstellációban - kifejezetten Győrre jellemző módon - formálják a fizikai, a mentális, illetve a megélt/ társadalmi teret, az önkormányzat lokális szerepe viszont csak a központi állammal kialakított kapcsolatában érthető meg. A dzsentrifikáció (városrehabilitáció) hatására átalakuló teret sokkal szélesebben értelmezem magánál a dzsentrifikálódó városrésznél. Abba, épp a lefebvre-i tértermelési folyamat komplexitásának ismeretében, beleértem a kiszorítottak megélt tereit is. E tértermelés megismeréséhez az aktuálisan zajló dzsentrifikáció tanulmányozása mellett fontosnak tartom annak egy korábbi termelési módban (az államszocializmusban) kezdődött, slumosodásként leírható előzményét is számba venni. Ezért, amikor e tanulmányban elsősorban az állam és a dzsentrifikáció (városrehabilitáció) miatt bekövetkező térbeli kiszorításnak kitett lakók viszonyát igyekszem megérteni, akkor a vizsgált terület korábbi és mai lakóinak a megélt tereit is tanulmányozom. A mellett érvelek, hogy az ily módon érintett kiszorítottak és az állam viszonya felől szemlélve - a Győrben is érzékelhető új gazdasági, államszervezési kontextusban - a mai Magyarországon egyfajta „államositott tértermelésról” beszélhetünk.

Ezen állításom kifejtését megalapozandó, a tanulmány következő fejezetében egy rövid elméleti, módszertani áttekintést adok, alapvetően arra koncentrálva, hogy miben is segít e megértési folyamatban Lefebvre (1991) térelmélete. Felvázolom továbbá azt is, hogy a kiszorításnak kitett lakosságot sem homogén társadalmi csoportként kezelve, hogyan tudom hasznosítani Castel (1993) „szociális kohézió zónái" koncepcióját. Ezek után Győr-Újváros főleg Kossuth utca környéki dzsentrifikációjának kontextusát elemezve, a fizikai mellett elsősorban az állam (tőkével együtt formált) elgondolt (absztrakt) terének változásait igyekszem bemutatni fejlesztési dokumentumok és szakértői interjúk segítségével. Ezt követően pedig a kiszorításban érintettek megélt (konkrét) tereit, azok átalakulását az államtól való függőség különböző „fokán” álló interjúpartnerek tapasztalatait elemezve jellemzem. A győri esetből kibontható általános tanulságokat az „államosított tértermelésre” vonatkozó felvetés továbbgondolását segíto logikában igyekszem levonni az összegző fejezetben.

\section{Elméleti, módszertani kérdések}

Mivel Lefebvre (1991) koncepciója a térről nemcsak elméleti kerete, de - bizonyos értelemben - tárgya is az itt bemutatandó kutatásnak, ezért annak leginkább használt elemeit/állításait érdemes számba venni.

Lefebvre $(2009,186$.) szerint a tér „folyamatosan termeli a társadalmi viszonyokat és a társadalmi viszonyok által termelt”. Az ő érdeklődésének középpontjában e társadalmi viszonyok állnak, s úgy véli, a társadalmi tér egy eszköz a 
társadalom elemzéséhez (Lefebvre 1991, 34.). Mivel a jelenlegi magyarországi városrehabilitáció/dzsentrifikáció okozta társadalmi-térbeli kiszorítás tanulmányozásával magam is a társadalmi viszonyok, elsősorban az állam és a kiszorításnak kitettek viszonyát igyekszem megérteni, a dzsentrifikációt tértermelésként értelmezve úgy vélem, hogy érdemes visszanyúlni a koncepció megalkotójához, s akár több gondolatot is hasznosítani Lefebvre nézeteiből.

Az egyik ilyen a térről való trialektikus gondolkodás, amit az angolszász földrajzban Soja (1996) tett különösen ismertté, illetve fejlesztett tovább (lásd erről Berki 2015). A térbeliség mint érzékelt, elgondolt, megélt, vagy más megfogalmazásban, térbeli gyakorlatok, a terek reprezentációi és a reprezentáció terei, illetve még további kontextusban fizikai, mentális és társadalmi, nemcsak azt a három módot jelenti, ahogyan megérthetjük a teret. Lefebvre (1991) történelmi példái rávilágítanak a tér minden ágens számára létező komplexitására, ugyanakkor azt is megmutatják, hogy az elgondolt teret alapvetően a tőke és az állam uralja, a megélt teret a lakosság használja, formálja cselekedeteivel, ami egyben az ellenállás tere is lehet számukra. A neoliberális kapitalizmus körülményei között zajló dzsentrifikációban meghatározó szerepet kap a tőke és az állam, s ezek viszonyára egyre nagyobb figyelem irányul a hazai tértudományokban is (pl. Timár, Nagy 2007; Bodnar, Molnar 2010; Jelinek 2011; Czirfusz et al. 2015). Az állam és a dzsentrifikációban, különösen a kiszorításban érintettek viszonyának tanulmányozására viszont szinte alig találni példát (Csanádi et al. 2006; Jelinek 2011). Ahhoz, hogy e térfolyamatra „alulnézetből” tekintsünk, elengedhetetlen a kritikai szemlélet, például olyan, mint aminek képviselőjeként Lefebvre (1971) nagy hangsúlyt fektet a mindennapi élet tanulmányozására. A társadalmi-térbeli kiszorításnak kitettek helyzetét központi kérdésnek tekintve, számomra is egyértelmü, hogy a tértermelésként felfogott dzsentrifikációról nem választhatók le e kiszorítottak drasztikusan változó, illetve a hatalmi viszonyok miatt változni kényszerülő megélt terei sem.

Lefebvre (1991) a tértermelést történelmi perspektívába helyezve megmutatta, hogy annak jellemzői az egyes korszakokban szoros összefüggésben állnak a mindenkor adott termelési móddal. A kapitalizmus a tér sajátos politikai gazdaságtanát hozza létre, amelynek egyik legfontosabb ismérve az, hogy az „absztrakt tér” kolonizálja a mindennapi életet. A piac és az állam csereértékként „kezeli” a teret, s a kommodifikáció és a bürokratizáció révén (a tértudományok és a tervezés közremüködésével) a mindennapi élet használati értékként működő „konkrét terét” igyekszik uralma alá vonni, csereértékké formálni (1. ábra). A rendszerváltás utáni másfél évtized magyarországi szuburbanizációjának kutatása alátámasztotta az effajta kolonizációnak a jelenlétét (Timár 2006). A magyarországi dzsentrifikáció, városrehabilitáció kiszorításra is rámutató vizsgálatainak ismeretében (még ha ezek többnyire nem is ebben a koncepcionális keretben gondolkodnak, illetve nem ennek megfelelő retorikát használnak) úgy vélem, nem jelent nagy kockázatot hasonló következtetés levonása ezekre a térfolyamatokra vonatkozó- 


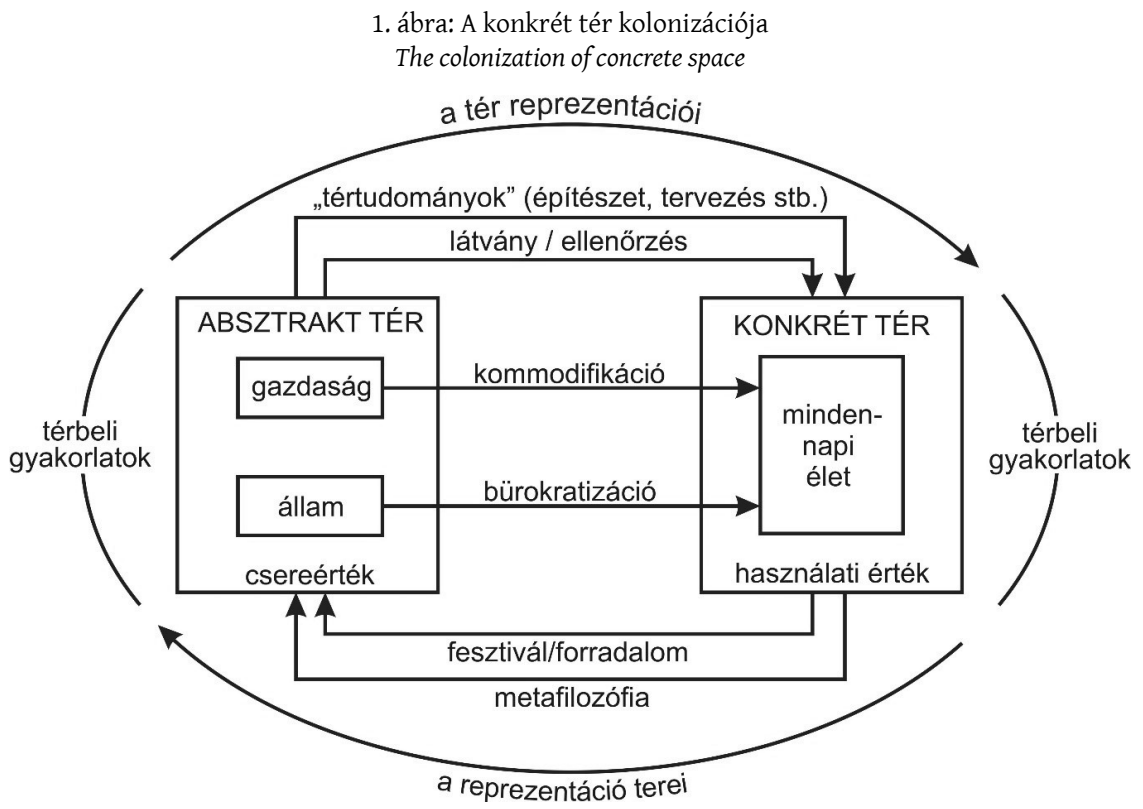

Forrás: Gregory 1994, 401.

an sem. Csakhogy maga a kapitalizmus, s vele az állam és a tőke viszonya is folyamatosan változik, térben és időben egyaránt. Ráadásul a társadalmi viszonyok újratermelésében rejl” „régi” feloldásának és „új” létrehozásának feszültségeit, ellentmondásait kifejező absztrakt tér jellegzetességeinek megfelelően a magyarországi dzsentrifikálódó városi terekben a régi és új kapitalizmusok rétegei közé az államszocializmusé is beékelődik, míg mindezekre a legutóbbi évtizedben az állam centralizált modelljének legújabb lenyomatai rakódnak rá. Lefebvre (1976) egykori ,jóslatának” beteljesülését, miszerint egy politikai centralizáció, centralizált döntéshozatal esetén az várható, hogy a térpolitika a múltbélinél (jóval) nagyobb egyenlőtlenségeket teremt, akár e folyóiratban is több hazai kutatást bemutató tanulmány igazolja (Czirfusz 2019; Jelinek 2019, Nagy, Nagy 2019; Velkey 2019). Úgy vélem, s érvelésemet az itt következő győri esettanulmány tanulságainak levonásakor részletezem, hogy a kapitalizmus jelenlegi magyarországi közegében s a kiszorítottak „harmadik” (megélt) terének (Soja 1996) perspektívájából nézve, a Lefebvre által a mindennapi élet gyarmatosításaként leírt folyamatot „államosított tértermelésnek” is tekinthetjük.

Lefebvre $(1991,2009)$ egyik legrészletesebben kifejtett kritikáját épp az állam szerepéról fogalmazza meg. Többek között a mellett érvel, hogy a kapitalista gazdaságban minden, így a tér mint használati érték is csereértékké változik át a homogenizáló állam fennhatósága alatt. Az általa definiált „állami termelési mód" (state mode of production) segítségével kontrollálja az állam a teret, a tér politikai eszközzé válik e cél érdekében. „Az állam olyan módon használja a teret, 
ami biztosítja a helyek feletti kontrollt, annak szigorú hierarchiájában, az egész homogenitását és a részek szegregációját [...]. A formális és kvantifikált absztrakt tér minden különbséget tagad, azt is, ami a természet vagy a történelem következménye, s azt is, ami a testből, életkorból, nemből és etnicitásból fakad." (Lefebvre $2009,188,189$.) Ezért is tartom fontosnak, hogy a társadalmi-térbeli kiszorításnak kitettek csoportját annak differenciáltságában vizsgáljam. Mivel pedig jelen kutatásban e csoport tagjainak az államhoz való viszonyára koncentrálok, különösen fontos ennek a relációnak a személyenkénti számbavétele is.

Hogy ezt megtehessem - módszertani megközelítésem második elemeként -, Castel (1993) „,szociális kohézió zónáiról” alkotott koncepcióját hívtam segítségül. E szerint az egyes személyek, társadalmi csoportok a betagolódás - legerősebb társadalmi kohéziót biztosító - társadalmi terétől („zónájától”) a sebezhetőség zónáján át a kiilleszkedési zónáig, azaz a munka nélküli lét és szociális elszigetelődés összekapcsolódásának övezetéig helyezkedhetnek el. ${ }^{2}$ Pozíciójukat két komponens, mint egy „koordinátarendszer” két tengelye jelöli ki. Az egyik a munkához való viszony tengelye (a becsatlakozástól a kizártságig terjedő skálával), a másik a társadalmi-családi társas kötelékek tengelye (a beilleszkedéstől az elszigetelődésig). Mindkét dimenzió menti kötelékek (de a helyi és központi államhoz való konkrét személyes viszonyaik is) rendkívül fontosak lehetnek például akkor is, amikor a városrehabilitáció során kilakoltatandó személyek arról döntenek, hogy az önkormányzat által felkínált cserelakást vagy a lelépési pénzt válasszák, ha egyáltalán lehetővé teszi még a társadalmi helyzetük e választást.

Mindezek érdekében 18 félig strukturált interjút készítettem 2016-2018-ban Győr-Újváros rehabilitált/rehabilitálandó részén (mindenek előtt a Kossuth utcában) korábban élő emberekkel, vagy épp kiköltözésre várókkal régi és új lakásukról, térbeli mobilitásuk okairól, körülményeiről, a városrészről alkotott képükről, a városrehabilitációról szerzett információikról, véleményükről, s általában életmódjukról, életkörülményeikről kérdezve őket. Interjúpartnereim többségével saját lakókörnyezetében beszélgettem (volt, akinek a korábbi és az újabb lakását is láthattam).

További 12 szakértővel is készítettem interjút, akik a kutatott városrész fizikai, mentális, társadalmi teréről, annak lakóiról adtak információkat, de alapvetően a hatalom által uralt Lefebvre-féle absztrakt tér megismerését segítették. Volt közöttük városi önkormányzati döntéshozó, hivatalnok, de föleg az adott városrészben, alapvetően annak szociális ellátó (családsegítö, gyermekjóléti, védőnői szolgálat, idősek klubja, családok átmeneti otthona) intézményében dolgozó, sőt akár Újvárosban lakó szakember. Az ő véleményük kontextusba helyezését, a fizikai tér változásainak, az állam elgondolt terének megértését segítette végül a Győr-Újváros városrehabilitációját előkészítő, befolyásoló önkormányzati tervek áttekintése. 


\section{Dzsentrifikáció és kiszorítás Győr-Újvárosban a helyi önkormányzat perspektívájából}

Az esettanulmány színhelyéül választott Győr-Újváros jelenlegi városrehabilitációval, dzsentrifikációval és kiszorítással leírható tértermelésében kifejeződő - elsősorban a helyi állam és a lakosság közötti - társadalmi viszonyok megértéséhez először az önkormányzat perspektívájából közelítek. Még ha ebben a kontextusban a szociális városrehabilitációs projektek miatt kulcsszereplőnek is tekintjük az önkormányzatot, nem hagyható figyelmen kívül a többi ágens sem, mint ahogy az sem, hogy a tőke, a nemzet- és a szupranacionális állam (EU) is olyan fizikai térben cselekszenek, illetve olyan térről „gondolkodnak”, amin korábbi történelmi korok aktorai, társadalmi viszonyai is nyomot hagytak.

A belvárossal határos, attól nyugati irányban hosszan elnyúló, északon az egykori Rábca-meder (ma Bercsényi liget), délen a Rába által határolt terület fó tengelye a hajdani történelmi város nyugati kapujához vezető Bécsi út, mai Kossuth Lajos utca, egyrészt az itt letelepedett gazdaság térformáló erejének, másrészt a történelmi város főleg vallási alapú társadalmi kiszorító hatásának köszönhette a kiépülését (2.a,b ábra). A Kossuth Lajos utca belvároshoz közelebbi része, a főleg a 18-19. századi zártsorú, egyemeletes lakóépületeivel az egykori polgári miliő emlékeit hordozza. Ezt a magterületet az I. világháború után telepszerüen beépített, kistelkes, családi házas övezet szegélyezi (Közösségi Beavatkozási Terv 2016). Az 1940-es évektől az ipar fejlődése a polgárságot arra késztette, hogy más városrészekbe költözzön, az államszocializmus kezdetén pedig az üzemek, mühelyek, boltok, majd lakóházak államosítása bérlő státuszba kényszerítette az egykori háztulajdonosokat, s helyet adott a munkásoknak. Az elmaradt állagmegóvás (sőt, egy 1984-es terv elfogadásáig az 1960-as években még lebontással járó lakótelep-fejlesztési elképzelés miatti építési tilalom) következtében egyre csökkenő használati értékű lakásokból, akik tehették, az 1970-es, '80-as években Győr másutt épülő lakótelepeire költöztek. A városi tanács folyamatosan alacsonyabb társadalmi státuszú embereket, főleg romákat telepített a helyükre. (Megalapozó vizsgálat 2014). Ehhez a politikához a későbbi önkormányzatnak is maradtak eszközei, még ha az 1990-es évek újkapitalizmusának nemzetállama utat is nyitott a lakások privatizációjának. Győrben 1993-ban az összes lakás 30\%a volt önkormányzati bérlakás (14652), de 1997-ben ez az arány már csak 11,2\%ot (5558 bérlakás), 2011-ben 7,9\%-ot ért el, ami azonban az országos átlagot még így is messze meghaladta (Nárai 1998; GYMJV Településfejlesztési Koncepció 2014). Nem véletlen, hogy Újváros szegregátumként lehatárolt, 2011-ben 384 lakosú részén (2b. ábra) a lakások többsége önkormányzati tulajdonban lévő, alacsony komfortfokozatú és alapterületű lakás (Közösségi Beavatkozási Terv 2016). Azt, hogy ezek bevételei nem fedezték a fenntartási költségeket, indokként használták arra a beruházás-visszatartási politikára, amit a mindenkori városvezetés az államszocializmus idején kezdett el, s a rendszerváltás után is folytatott. 
2.a ábra: Győr városrészei Urban quarters of Györ

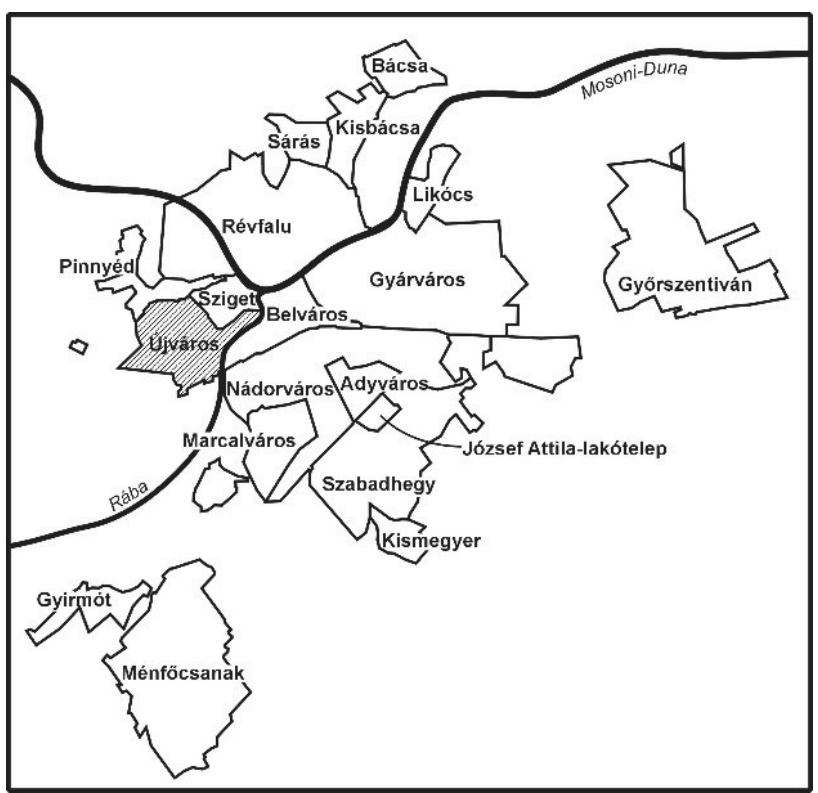

Forrás: Páthy 2014, 52. alapján

2.b ábra: Szegregátum és szegregációval veszélyeztetett terület Győr-Újvárosban Segregated areas and areas threatened by segregation in Györ-Ujváros

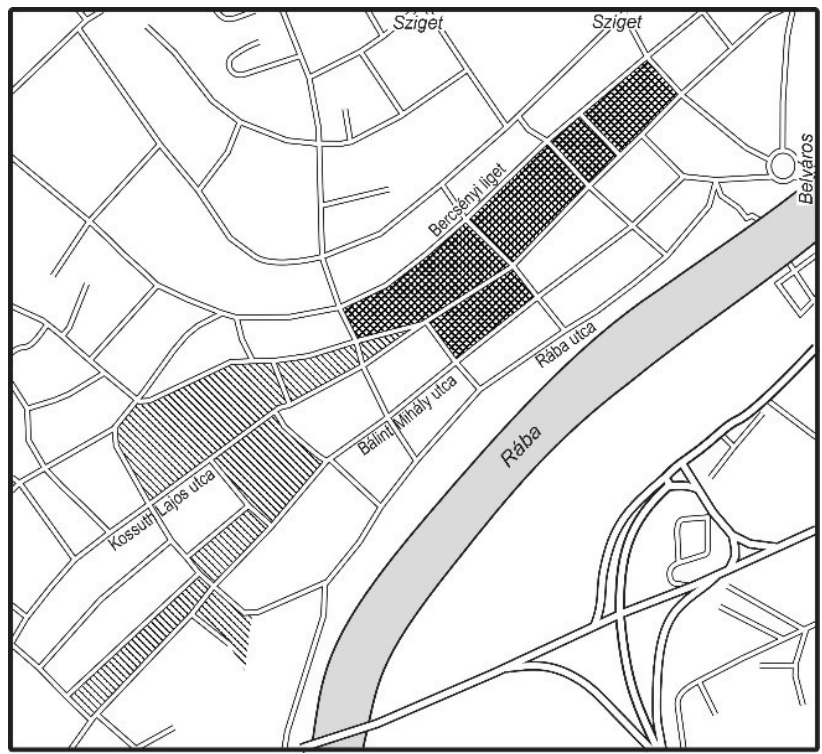

Forrás: Közösségi Beavatkozási Terv 2016, 9., 10. alapján 
A piaci viszonyok kialakulása, a szomszédos belváros felértékelődése az 1980-as években megindult városrehabilitációnak és infrastruktúrafejlesztéseknek köszönhetően, főleg a Rába part melletti Rába és Bálint utcában értelmiségiek, művészek lakásvásárlásaival kezdődő spontán dzsentrifikációt hozott magával. A 2000-2010-es években az egyik oldalon lendületet vettek a beruházások, a Jedlik híd megépítése, a Zsinagóga felújítása, a közelben lévő termálfürdő építése, illetve turisztikai fejlesztések, melyeket hosszú távon állami szabályozások, így Újváros mủemléki jelentőségű területté nyilvánítása is segített (Megalapozó vizsgálat 2014). A másikon folytatódott a Kossuth utca, Bercsényi liget, s a belsőbb újvárosi részek slumosodása, szegregálódása (2.b ábra). Ezek együtt sürgetővé tettek egy szociális rehabilitációt, amit az EU-s forrásokra építő központi állami politika (Jelinek 2019) és a város tőkeereje lehetővé is tett, sőt ösztönzött. Így 2012-13-ban a Bercsényi ligeti szabadidős célú területkialakítások, egy iskola és egy templom felújítása, a közvilágítás és az utcaburkolat megújítása és „soft projektek" mellett a Kossuth utcán 6 műemléki védettségü önkormányzati tulajdonú lakóépület felújítását, azokban 40 modern szociális bérlakás, 5 üzlethelyiség és 1 rendőrségi iroda kialakítását végezték el (GYMJV Településfejlesztési Koncepció 2014; Közösségi Beavatkozási Terv 2016; Fekete, Polgári 2016). A többszintű állami részvétellel zajló felújítás következtében meginduló dzsentrifikáció messze túlterjedt e projekt célterületén. 2012-ben ugyanis az önkormányzat megpályázta és kormányzati segítséggel sikerre vitte (Nagy, Nagy 2019) a 2017-es Európai Ifjúsági Olimpiai Fesztivál (EYOF) rendezését, melyet az infrastruktúrafejlesztések mellett az ingatlanberuházások részeként a rendezvény után értékesített lakások (Olimpiai sétány a szomszédos Sziget városrész területén) s az azóta odavonzott tőke segítségével folytatódó lakásépítések követtek (Megalapozó vizsgálat 2014). Ez tehát már egyértelműen a tőke és az állam összekapcsolódásával zajló tértermelés: dzsentrifikáció. Ennek legújabb elemeként a 2016-2020 közötti időszakban Győr-Újváros szociális városrehabilitációjának II. üteme is elindulhatott a TOP 6.7.1 -15 program keretében, melynek segítségével a Kossuth utca további 4 épületében 30 lakóházat újítanak fel, s amit a TOP-6.9.1-15 program részeként ,a társadalmi hátrányok kompenzálását célzó” szociális stb. fejlesztések egészítenek ki (Közösségi Beavatkozási Terv 2016, 89.).

Az önkormányzat városrehabilitációval kapcsolatos tervekben kirajzolódó „elgondolt terében" nincs írásos nyoma a dzsentrifikációnak (még kevésbé a kiszorításnak). A társadalmi tér ezekben kettéválni látszik egy fizikai térre és a társadalomra. A Településfejlesztési Koncepcióban (2014-2030) a „városrehabilitáció folytatása" (mint tömbrehabilitáció és -feltárás, műemléki területek megóvása és értékőrző megújítása) közterület-megújítással és a minőségi lakókörnyezet megteremtésével (így az önkormányzati bérlakás-állomány arányának növelése, egészséges lakókörnyezet biztosítása és slumosodás elleni harc) összekapcsolva jelenti az épített környezet fejlesztésének átfogó célját. A társadalomfejlesztés átfogó céljának elemeiből ugyanakkor e tanulmány szempontjából legfontosabb az, 
hogy a helyi társadalom „legyen kiemelkedően aktív és egészséges” s „a városon belüli társadalmi különbségek maradjanak fenntartható és kezelhető mértéküek” (GYMJV Településfejlesztési Koncepció 2014, 10.). Még ha a „különbségek” kezelhetőségének kívánalmába ,jóindulatúan” egyenlőtlenségcsökkentést is látunk bele, az rejtve marad, hogy mi az önkormányzat szándéka a felújítandó épületek lakosaival. Bármily sikeresek az Újváros rehabilitálandó területén élők számára szervezett, társadalmi integrációt célzó „soft” programok, az elgondolt tér ilyen megformálása minden további nélkül lehetővé teszi azt, hogy a fizikai teret egészen más (magasabb státuszú) népesség uralja a rehabilitáció után, mint az elött.

Ennek az írásnak a lehetőségeit meghaladja, de érdemes lenne alapos elemzés tárgyává tenni a központi és a helyi állam viszonyát a tervezési gyakorlatban, ${ }^{3} \mathrm{~s}$ megvizsgálni, hogy az önkormányzati tervek eltérő tartalma mennyiben függ a kormány rendeletalkotásban (tervezési útmutatókban) kifejeződő, változó szándékától, és mennyire a helyi döntésektől. A 2008-as győri IVS még rögzítette a „rehabilitációval, rekonstrukcióval kapcsolatos lakáscserék, lakásleürítések” mechanizmusával kapcsolatos elveket. Felvázolt egy „mobilizációs programot”, ami „az újvárosi célterületen élő és a rehabilitációs program által érintett alacsony státuszú lakosság kiköltözésének az integrációs alapelvet követő megoldását teszi lehetővé" (GYMJV IVS 2008, 299-300.). A tervezet szerint az újvárosi (ekkor még nem „szociális”) rehabilitáció programjával 72 bérlemény érintett, amiből „29 bérlő mobilizációja szükséges, a többi 43 bérlő részben visszaköltözik a fejlesztési programot követően, részben korábban megtörtént az elhelyezésük" (közülük 17 bérlőt - volt, akit 10 évvel korábban - elhelyeztek, s már üresen állt a lakás: GYMJV IVS 2008, 311.). A később megvalósult szociális városrehabilitáció I. ütemét (2013-14) illetően azonban már csupán a szakértői interjúk során szerzett információkból sikerült megtudni, hogy a 40 kialakítandó lakásból mindössze ötben vállalta fel a program az ott lakók visszaköltöztetését. A II. ütem kapcsán már ilyen kvótáról sem tudtak az általam megkérdezettek - meglehetősen nagy volt a bizonytalanság.

Az önkormányzatnak Újváros és azon belül a szegregálódott-rehabilitált területek átalakulására vonatkozó hivatalosan rögzített értékelései - objektivitást sugallva - számokban, statisztikákban kifejezve olvashatók. Ezek részben a lakások komfortfokozatában, részben az érintett városrészben lakók demográfiai mutatóiban, különösen az iskolai végzettségben láttatnak pozitív elmozdulást (GYMJV Településfejlesztési Koncepció 2014; Közösségi Beavatkozási Terv 2016). Csakhogy a számokból itt sem derül ki az azokkal jellemzett terület lakóinak cserélődése - az absztrakt térben absztrakttá merevedik a társadalom. Márpedig azok a fókuszcsoportos interjúk, melyekben Újváros szegregálódó/szegregált részének problémáiról, az ott felmerülő szükségletekről, fejlesztési lehetőségeiről kérdeztek meg 2016-ban (önkormányzati alkalmazotti) szakértőket, egyértelmüen rávilágítottak az ország számos más rehabilitált helyén (Terra Studió Kft. 2016) 
is tapasztalt kiszorítási folyamatra. „A hátrányos helyzetű csoportok száma ugyan csökkent a korábbi rehabilitációs programok révén, de főként a városrész külterületeire tolódnak, így a problémák nem tűnnek el, csak a térben áthelyeződnek" (Közösségi Beavatkozási Terv 2016, 40.).

Magukat az önkormányzati lakások felújításához kapcsolódó kiköltöztetéseket, illetve ebben a folyamatban a helyi állam és az érintett lakók viszonyát az általam megkérdezett önkormányzati döntéshozók, alkalmazottak sikeresnek értékelik. Kétségtelen, hogy az IVS-ben lefektetett mobilizációs elvek, a személyenkénti egyeztetések, a bérleti jog pénzbeli megváltása és a cserelakás választhatósága, a korábbinál lehetőleg jobb lakásviszonyok biztosítása, a segítő-támogató intézmények bevonása és a „soft” programok nagyobb kompromisszumkészségről tettek tanúbizonyságot, mint a másutt szerzett korábbi kutatási tapasztalataink mutatták (Timár, Nagy 2007). Ebben a város jelentősebb anyagi ereje, az EU-s források eléréséhez szükséges integrált városfejlesztés elveinek átvétele, a városrehabilitáció központi kormányzati szinten átalakult finanszírozási politikája (Jelinek 2019) éppúgy közrejátszhatott, mint egy toleránsabb attitüd. Arra a kérdésre viszont, hogy a kiköltöztetettek zöme miért nem tér(het) vissza bérelt lakásába a rehabilitáció után, meglehetősen jellemző (más városban is leírt, pl. Aczél 2011) válaszként adták: „,nem is akarnak már visszajönni”. Ennek ellentmondani látszik az a 2013-ban a városban 3032 fővel készített, nemre, korra, városrészre reprezentatív kérdőíves felmérés (Csizmadia, Tóth 2014), amely szerint az Újvárosban élők más városrészbe költözési szándéka (11,35\%) a költözni nem akarókkal szemben (87,59\%) nagyságrendileg kisebb, s a városi átlagnál sem sokkal erősebb (9,30\%) (Tóth, Ditrói 2014). Azt, hogy a visszaköltözni nem akarás korántsem feltétlen szabad döntés eredménye, a polgármesteri hivatal egyik szakembere a „házleürítések” során szerinte egyébként együttműködő bérlőkkel sikeresen meghozott kompromisszumok ecsetelése végén maga is kimondta:

„.... azért ezt tudni kell, hogy a felújitott lakásoknak a bérleti día, az jóval magasabb, mint az eredeti lakásoknak a bérleti dija, mert ezek a lakások már összkomfortosak lettek, és mivel olyan a lakbér-megállapítási rendszer, hogy több tényezőt vesz figyelembe, és ezek közül a tényezók közül az egyik az, hogy mikor volt felújitva az ingatlan, ezért lényegesen megemelkedtek a bérleti dijak. Szóval többszörösére. Ezt a többszörösét úgy kell értelmezni, hogy eddig fizetett négyet, most meg tizenhatot. Az nagyon sok. Nagyon sokan emiatt sem akartak visszaköltözni".

Ez a társadalmi-térbeli kiszorítás és dzsentrifikáció végeredményben annak a jövőképnek a megvalósulását szolgálja, ami Újvárost újra be kívánja kapcsolni „Győr lüktető vérkeringésébe” (Közösségi Beavatkozási Terv 2016, 24.). Ez nyilvánvalóan a középosztállyal érhető el, akinek az idevonzására nagyon is reális esély van. Az egyik szakértő interjúpartner kiemelte a gazdasági fellendülés miatt a lakáspiacon folyamatosan jelenlevő kereslet fontosságát. Újváros Bercsényi ligethez közeli részein egymás után épülnek a társasházak e réteg igényeit szem előtt tartva. Ez az ingatlanpiaci trend hozzájárul a város növekedési pályán tartá- 
sához is, ami viszont összhangban van a kormány politikájával, a nagyobb városokra koncentrált fejlesztéssel (a Modern Városok Programmal), illetve az EU hasonló törekvéseivel.

\section{Az újvárosi lakók megélt tereinek változásai}

A Győr-Újváros rehabilitációját megelőző slumosodással, majd kiszorítással érintett, illetve veszélyeztetett, 2016 nyarán (és egy ismétlő interjúban 2018-ban) megkérdezett, korábban vagy akkor a kerületben lakók (18fö) között megtalálható volt az egykori lakásfoglalótól a lakásmaffia áldozatán át a rehabilitáció alatt lakást vásárolt s a városrészből már elköltözött, vagy épp ideköltöztetett interjúpartner is. Volt köztük idős, fiatal, fogyatékkal élo", férfi, nő, egy- vagy többszemélyes háztartásban élő személy is, de jellemzően alacsony társadalmi státuszúak, akik rövidebb vagy hosszabb ideig, sőt, akár egész eddigi életükben állami (önkormányzati) lakásban éltek. Nagy többségük életútjának ismeretében mindennapi életük konkrét terei összevethetővé váltak a helyi állam (nemzetállammal, EU-val, valamint a magántőkével összefonódva formálódó) absztrakt terével. E változó terek viszonyának megismerésén túl a kérdés az, hogy mennyire tudnak e városlakók aktív szereplőként részt venni megélt tereik termelésében, a lakásuk mikrotere és tágabb lakókörnyezetük, Győr-Újváros, illetve annak bizonyos részei alakításában.

Ami a városrészt illeti, az, aki több évtizede ismerte/használta, a lepusztulásáról panaszkodott (3. ábra), nosztalgiával gondolva vissza a többlakásos régi házakra s a környékre: „ó, arany volt, virágágyással volt tele az udvar, aztán lejjebb ment/ mentek el innét lakni; már utólag olyan lakók voltak - azok romboltak. Amikor az édesanyám megkapta [ezt a lakást], itt virágágy volt". A lakókörnyezet e több évtized távlatából visszaidézett múltja sokkal közelebb van az emlékezőkhöz, mint a fizikai térben már csak két-három háztömbnyire lévő, de hatalmas társadalmi távolságba került rehabilitált/dzsentrifikált Kossuth utcai környék (4. ábra). Ez a távolság még annak a - kivételesen egy felújított házba - betelepített, hátrányos helyzetű fiatal családanyának a szavaiban is felismerhető volt, aki csupán az útlezárások miatt „keveredett” egyszer a pár utcányira lévo, beszélgetésünkkor még épülo „olimpiai faluba", s bár azt igen szépnek találta, csalódott is lett, mivel azzal kellett szembesülnie, hogy bevásárlóközpontot ott sem építenek. A kiskereskedelmi ellátást ugyanis - mint más Kossuth utca környékiek is - rossznak, s a számukra nehezen megközelíthető bevásárlóközpontokhoz viszonyítva kifejezetten drágának tartja (Nagy, Nagy 2019). A fizikai tér folyamatos megszépülését ezen kívül csak egy interjúpartner észrevételezte. ő, a megkérdezettek között az egyetlen középosztálybeli, a rehabilitáció után a korábban bérelt önkormányzati lakásába visszaköltözött értelmiségi lakó, ma is sokkal élhetőbbnek látja a környéket, mint a többiek. Dicsérte például a Rába és Bálint utcának azokat a magántulajdonú háza- 
3. ábra: Győr-Újváros slumosodó utcarésze Urban decay in Győr-Ujjváros

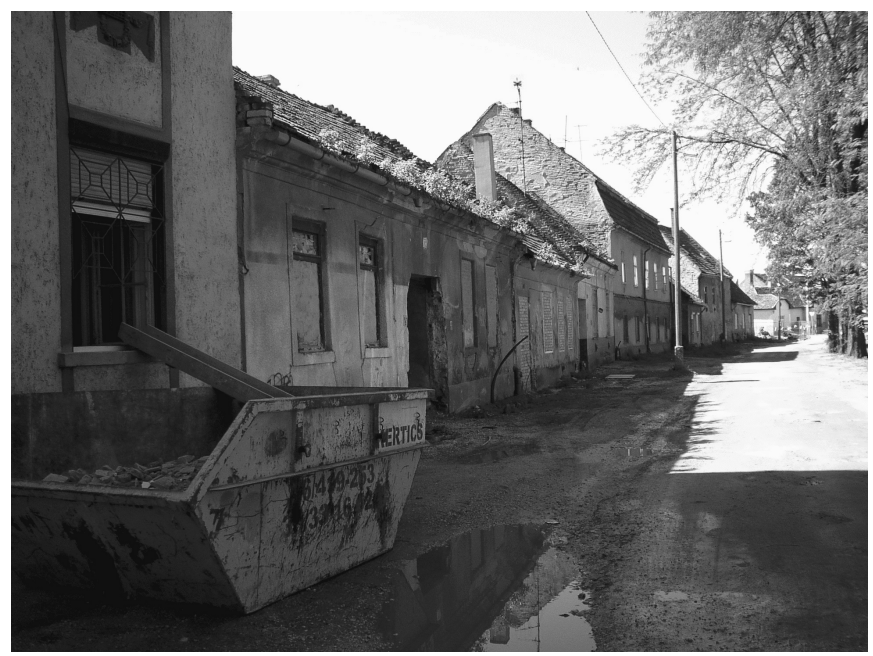

Forrás: saját fotó

it, amelyeket a beköltöző építészek újíttattak fel. Mégis, a saját gyermekeit már az 1980-as években sem a - többek között szerinte is akkor még jobb közeget teremtő - Kossuth utcai általános iskolába járatta. Amíg tehát ő a lakóterét és a környező köztereket egyaránt „magáénak” érzi, addig gyermekeit nem akarta a legközelebbi állami nevelési tér részévé tenni (e jelenségről lásd általánosabban Velkey 2019).

4. ábra: Győr-Újváros egy rehabilitált része Urban rehabilitation in Györ-Ujjuáros

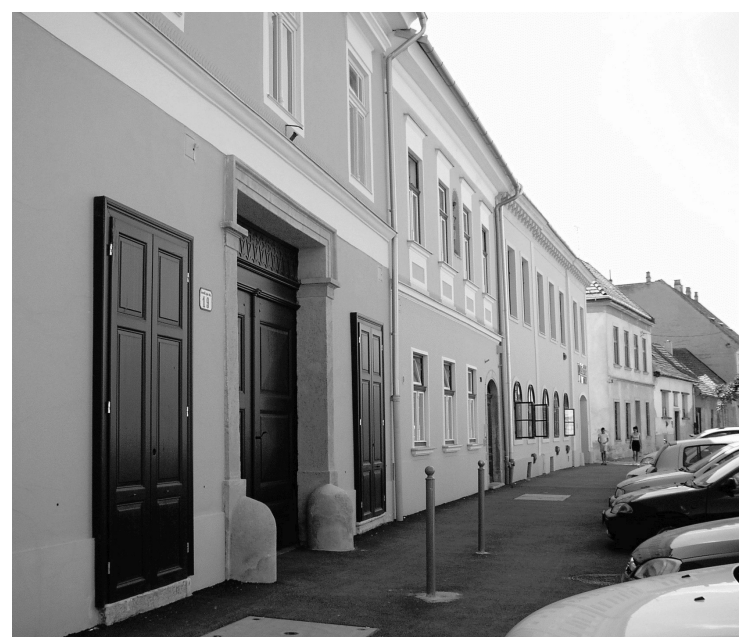

Forrás: saját fotó 
A megkérdezettek az újvárosi rehabilitációval, dzsentrifikációval közvetlenül saját lakásuk (mikroterük) változásán keresztül érzékelnek kapcsolatot. Az ifjúsági olimpiához (EYOF) köthető beruházások miatt a szomszédos Sziget városrészben bekövetkezett rendkívül gyors ingatlanár-emelkedés például kifejezetten rosszul érintette az egyik interjúpartnert. Ennek következtében hiúsult meg ugyanis a számára az előző (önkormányzati) lakásából való kényszerű távozása idején még elérhetőnek tűnő egyik lakás megvásárlása a „lelépési pénzből”. Volt, aki bérlőből egy, a rehabilitációban nem érintett, viszonylag jó állapotban lévő épületben még a '90-es évek elején szerzett lakástulajdonosi pozíciója ellenére is aggódott a házfelújítások miatt. Arról szerzett ugyanis tudomást, hogy a kiürítés alatt álló többlakásos szomszéd házat el akarja adni az önkormányzat (majd szállodává alakítása után őket egy fallal akarják attól az épülettől elválasztani). Ráadásul 2015-ben a már érzékelhető ingatlanfelértékelődés hatására már az ő társasházukat is meg akarta tőlük venni a helyi elit egyik, önkormányzati fejlesztésekről és ingatlanpiaci folyamatokról információkkal bíró, befolyásos tagja. Mint elmondta, ők ennek hatására egy közgyűlésükön a saját közös költségük megemelését határozták el, hogy elegendő tartalékot képezzenek a szükségessé váló felújításokra, többek között ilyen érvekkel: „Gondolkodjatok, ha nem lesz pénzünk a felújitásra, elveszik tölünk, kiszoritanak minket a lakásból. Hova mész, mit csinálsz, elmész hatvanezer forintos albérletbe?" Úgy tűnik, hogy a központi és a helyi állam és az ingatlanfejlesztők, valamint a vállalkozók alkotta koalíció olyan, a város gazdasági növekedését fenntartó lakáspiaci folyamatokat indított el, melyek tovább polarizálják a lakosságot, s akár lakástulajdonosi rétegeket is hátrányosan érinthetnek.

A megkérdezettek számára a fizikai tér felértékelődésénél sokkal fontosabb Újvárosnak a mindennapi életüket közvetlenül érintő, még nagyon is érzékelhető slumosodása. Megélt tereik ebben a léptékben leginkább azáltal formálódtak egységessé, hogy a városrészben (illetve a Kossuth utca környékén) a drogfogyasztást komoly problémaként írták le: elszaporodtak emiatt az éjszakai lakásfoglalások, szemetelések, hangoskodások, kéregetések, lopások. Ez az imázs pedig összhangban látszik állni a fentebb már említett, 2013-as győri kérdőíves felmérés eredményeivel. Akkor a lakosság a „szegény”, „zárkózott”, „iskolázatlan” problémák mellett a „rossz közbiztonságot” az egyes városrészek közül egyértelműen Újvároshoz kötötte leginkább (Páthy 2014). Ennél a mi kutatásunk interjúpartnerei annyiban látják csak jobbnak a környezetüket, ha mérlegre teszik, hogy Adyvárosban rosszabbnak ítélik a közbiztonságot. Máshonnan ideköltözött interjúpartnerünk ${ }^{4}$ viszont már egyértelműen internalizálja a negatív imázst: „mikor megkérdezik, hogy merre lakok, nem merem kimondani, hogy hol, mert egy kalap alá vesznek sajnos". Ez pedig már a Wacquant (2011) által a fejlett marginalizáció kapcsán azonosított lakóhely alapján történő megbélyegzésnek, a többi idézett vélemény pedig az otthon érzetét adó, ismerős „hely” eltűnésének, kiüresedett „térré” válásának állapotát írja le. 
E városrészpusztulás magyarázatát legtöbben a romák 1980-as évektől induló betelepítésében, a későbbi, korántsem csak a romákra érvényes elszegényedésben, az egyesek szerint „álszegény” betelepült romániai (nagyrészt) romák életmódjában találják. Egymás „nevelése” még felnőtt-gyermek viszonylatban sem müködik már a köztereken, épp a drogozáshoz kapcsolt agresszivitástól való félelem miatt, legalábbis ahogy azt néhány nő interjúpartnerem elpanaszolta. Megoldást az önkormányzattól, illetve a rendőrségtől várnak. Sikeres intézkedésről azonban csak egyikük számolt be, akinek a másokkal közös udvarán befalazták a már kiürült lakások ablakait, ajtóit, hogy ne mehessenek be oda éjszakánként a „drogosok”. Azonban ezt is csak egy családsegít” munkatárs közvetítésével tudta elérni.

Azt feltételezhetnénk, hogy a személyes terek, az otthonok/lakások jelenthetnék azt a léptéket, ahol a mindennapi élet szabadsága megvalósulhatna, a megélt tér az ott élők megelégedésére, általuk volna formálható. A léptékek termelésének (Berki 2017) változó összefonódása, azaz a városrész és a lakás mint életterek sokféle egybefüződése miatt azonban ez az eredményesség a vizsgált hátrányos helyzetű csoport számára akkor sem feltétlenül valósul meg, ha a városrehabilitáció részeként kapott lelépési pénznek köszönhetően a bérlő jogviszonyt egy lakásvásárlás során tulajdonosira alakítják. Egyik interjúpartnerem arra a számos városban megtapasztalható jelenségre nyújt példát, amikor a lelépéskor kapott összeg (esetében mindössze 2,5 millió Ft) csak arra volt elegendő, hogy a kerületperemi egykori zártkerti részen - mint a társadalmi-térbeli kiszorítás több más győri elszenvedője - egy hétvégi házat vegyen meg lakáshasználatra. ${ }^{5}$ Ezt a településrészt a megfelelő közszolgáltatások híján nem állandó lakásra tervezték, hiányzik pl. a közvilágítás, „még az utcaneveket sem írták ki”, , a körzeti orvos se megy ki". Az önkormányzat elgondolt terében pedig ez a városrész nem szerepel a megújításra kijelöltek között, így a közszolgáltatásokkal kapcsolatos kérések nem találnak meghallgatásra - e városperem ellátási gondja a személyesen megélt tér kisebb léptékének, az otthonnak a használati értékét is erősen lerontja. Ugyanezek a mechanizmusok vezettek annak az interjúpartnernek a helyzetéhez is, aki nehezen, és saját bevallása szerint is a bürokrácia egy véletlen anomáliája miatt tudott a fentinél nagyságrenddel magasabb lelépési összeget kialkudni magának. Ebből sikerült Újváros belső részén egy földszintes épületben lakást vásárolnia, sőt, azt belül fel is újítania. A szomszéd ház viszont mintegy szeméttárolóként működve a teljes lepusztulás állapotában van; az egyik bank, mint hitelezőből lett új tulajdonos nem gondoskodik a megtisztításáról, az önkormányzat pedig nem segít a probléma megoldásában.

Azok az interjúpartnerek, akik önkormányzati lakásból másik önkormányzatiba kerültek, vagy beszélgetésünk idején vártak cserelakásra, nemcsak azt élték meg, hogy minimális befolyásuk van térbeli mobilitásukra, de azt is, hogy a tulajdonos állam kontrollja a mindennapi életük szférájába hatol. ${ }^{6} \mathrm{Ami}$ az önkormányzat részéről nehéz, de tárgyalásokkal elért kompromisszumnak látszik, az a 
megkérdezett kitelepítendő bérlők perspektívájából döntően a helyi állammal folytatandó egyenlőtlen harcnak tünik. Különösen azért, mert ők is eleve „kompromisszumosnak" gondolják az egyéni helyzetekből adódó kéréseiket: „nem nagyobb lakást, csak kétszobást" szeretne valaki, a gyermekeire hivatkozva, vagy olyat, amihez tartozik tároló, hogy a megélhetéséhez elengedhetetlen biciklit tudják hova tenni. Nehéz elfogadniuk az ellenérveket, ha például érthetetlen bürokratikus szabályozás áll mögöttük. Mint annak a mozgáskorlátozott érintettnek az esetében, aki szerette volna, ha az egyébként akkor felújított szép cserelakásba nem padlószőnyeget tesznek le, mivel azon nehezebb mozogni járókerettel, de a negatív választ jogszabályokkal indokolták neki. Nehéz a választásuk szabadságának korlátozását elfogadni akkor is, ha egyenlőtlen elbánást feltételeznek az eljárásban (alkukban). Ha valaki lelépési pénzt remélt, de helyette lakást kapott, biztosan ismer olyat, akit „,bezzeg nagy összeggel fizettek ki”. Ha vele szigorúak abban, hogy a harmadik felkínált lakás után már nem válogathat, olyanra hivatkozik, akinek „már ötöt is ajánlottak”. A függőségi viszony bevésődik egy-egy valóban elhangzott vagy a rossz emlék által eltorzított mondatba: ,mit gondol, épitsünk magának házat?" Amit szinte egyöntetűen megtapasztaltak, az az információhiány. Nem tudják, hogy mikor, mi lesz az ő lakásukkal, velük, a szomszéd házzal, s ez a bérlők mellett akár a már tulajdonosi pozícióban lévőkre is igaz lehet. Utóbbiak egyike, egy társasházban lakástulajdonos elmondása szerint: „Engem az bosszant, az az egy, hogy most már itt müködnek, itt is most már kb. egy éve járnak ide, de egy kukkot nem szólnak, hogy mit akarnak. Küldik az embereket ide, fényképeznek, rajzolnak, elmennek, holott, nyolcvan százalékban magántulajdonosok vagyunk."

Végeredményben megállapítható, hogy az önkormányzat által uralt tértermelés jelenlegi gyakorlata az államnak leginkább kiszolgáltatott lakókat elidegeníti saját mikrotereiktől (otthonaiktól) is. Konkrét tereik - használati értéküket elveszítve - az állam elgondolt terének fizikai valóságává, csereértékké válnak. Ez ellen fellépni, az ellenállás mikrotereit létrehozni csak törvényszegéssel tudnak, amit eltitkolva még lehet esélyük ideig-óráig a bérleményeik megtartására (például műemlék jellegü épületben végzett, engedély nélküli olyan kisebb költségü átalakítás, mint egy gipszkartonfallal történő térleválasztás). Vagy épp az építési szabályok magas szintű ismeretével és kiváló kapcsolatrendszerrel kiharcolhatnak maguknak valamilyen átalakítást (természetesen saját költségen). A jelen kutatásban résztvevő csoport társadalmi helyzetében (az előbb is említett értelmiségi család kivételével) azonban ennél még az is reálisabb lehetőség, hogy úgy találjanak kiutat az önkormányzat által menedzselt rehabilitációban megélt alárendelt helyzetükből, hogy kimenekülnek mostani lakóhelyükről, beleértve magát a slumosodó városrészt is. Castel (1993) modelljét alapul véve, ebben a kutatásban erre egy olyan, már említett, „rossz helyen” lakást vásárolt interjúpartnernek látszott esélye, akit a családi-rokoni kapcsolatok erőssége még a „beilleszkedés” pozíciójában tartott. Korábban az ő anyagi segítségével voltak képesek a fiáék kiköltöztetésénél együtt olyan helyzetet teremteni, aminek köszönhetően azok a lelépési pénzt ki- 
egészítve tudtak egy kis családi házat venni a városperemen. Most ő bízik abban, hogy ha végképp „menekülni” akar, akkor hozzájuk költözhet. A másik példa egy olyan család, amelyet a három együtt élő felnőtt változó összetételü, de folyamatos fizetett munkája a „betagolódás” pozíciójában tartott a társadalmi térben, legalább annyira, hogy ők is vásárolhattak egy házat Újváros családi házas övezetében. Annak a nagy többségnek viszont, akiknél egyik ilyen társadalmi kötelék sem elég szilárd, s a Castel (1993) által leírt modell szerint a társadalmi térben a „sebezhetőség” vagy már a „kiilleszkedés” zónájában helyezkednek el, semmi esélyük az efféle ellenállásra. Abban azonban vitatkoznék e társadalmi kohézió mértéke alapján osztályozó modell alkotójával, hogy szerinte a gazdasági rétegződés kevésbé fontos, mondván, hogy a társadalmi beavatkozásra szorulók szinte valamennyi szereplője „szegény”. Épp abban a körben ugyanis, ahol a fent említett térbeli mobilitás egyfajta menekülési út lehetne, már a családi kötelékek ereje sem segít, hiszen a rokonoknak sincs lakása. Hiányzik a hátország, ami a stigmatizáció mellett szintén fontos jellemzője a Wacquant (2011) által leírt, fentebb idézett fejlett marginalitásnak. A városrehabilitációban érintettek között jó néhányan lehetnek a „segélyezés zónájában", melyben a munka nélkül való lét ellenére az állami ellátás által teremtett szoros kötelék miatt még betagolódnak a társadalomba. Az önkormányzati lakások (és más állami segítség) révén ide tartozók azonban, mint azt az itt bemutatott tértermelésben az aktivitásuktól megfosztottak államhoz füződő viszonya is mutatja, a „magára nem hagyott függő kiszolgáltatottság” zónáját foglalják el a társadalmi térben, ami semmiképp sem hasonlítható a „munka révén kivívott autonóm becsatlakozás zónájához” (Castel 1993).

Végül, itt kell megjegyezni, hogy az „elmenekülés” szándéka nem azt jelenti, hogy a kiszorítással fenyegetettek ne szeretnének egy valóban „szociális” rehabilitáció részesei lenni, vagyis egy felújított városrész megfelelően felújított házába visszaköltözni a korábban bérelt lakásukba. Ez a szándék azonban azért nem kap hangot, mert egyrészt joggal feltételezik, hogy az ott megemelkedő lakbért és rezsit nem tudnák megfizetni, másrészt esélyt sem látnak arra, hogy ezeket a lakásokat ők kaphatnák vissza. Az az interjúpartner, aki megpróbálta ezt kérni, így nyilatkozott: „Áááá, mondtuk mi [az ügyintézőnek], mi mondtuk. Azt mondta, szó sem lehet róla!" Mindezek a tapasztalatok jól példázzák, hogyan zárhatja ki a tulajdonosi szerepben lévő helyi állam a bérlőit a megélt terükről (otthonukról) szóló érdemi döntésekből is a középosztálybeli városiak, a tőke és az állam szükségleteit beteljesítő dzsentrifikáció megvalósításáért szervezett térbeli kiszorítás segítségével.

\section{Összegző következtetések}

A győri újvárosi szociális városrehabilitáció társadalmi-térbeli kiszorítást eredményező gyakorlatának feltárása révén jelen tanulmány is a kritikai városkutatók 
érveléséhez csatlakozik. A dzsentrifikáció pozitív és negatív hatásairól vitatkozó nemzetközi diskurzusban (Berényi 2016) az ide vonatkozó szakirodalmat áttekintve Atkinson (2004, idézi Lees et al. 2008) azt találta, hogy a dzsentrifikációt túlnyomó többségben „negatív szomszédsági” folyamatként értékelték a kutatók. Miközben egyetértek azokkal, akik szerint a kiszorítottak egyébként rendkívül nehéz számszerűsítése segíthetne rámutatni a kiszorítást eredményező dzsentrifikációs politikák tarthatatlanságára (Lees et al. 2008, Easton et al. 2019), meggyőződésem, hogy a kvalitatív módszerekkel megismerhető lakossági tapasztalatok is rámutathatnak a kiszorítási gyakorlatok müködési módjára.

Lefebvre (1991) trialektikus térfelfogása kiváló eszköz arra, hogy a tértermelés szereplőit akár egy városrész átalakítása kapcsán „szembesítsük egymással”. Ebben a tanulmányban mindezt a kiszorításnak kitett embereket középpontba helyezve, s az ő megélt tereiket - többek között - az önkormányzat elgondolt terével együtt vizsgálva igyekeztem megérteni. A 2010-es évektől kiépített centralizált állami rendszerben az EU-s források elérését megcélzó, a központi állam által szabályozott tervezési gyakorlat lehetőséget adott a helyi önkormányzatoknak az absztrakt térben megjelenített társadalom valós térbeli mobilitási folyamatainak, a kiszorításnak a leleplezésére.

Az esettanulmány olyan gyakorlatokat tárt fel, amelyekben egyértelműsítette a térbeli elidegenedés/elidegenítés mechanizmusát. A felújítandó önkormányzati lakásokban élők sem a városrészt, sem saját mikrotereiket nem érzik magukénak, az információhiány bizonytalanságban, „kívülálló” pozícióban tartja őket, a szociális rehabilitációs projektben „célcsoportnak” tűnő szereplőket. Az állami kontroll eközben behatol a magántereikbe is, folyamatosan fenntartva a függőség viszonyait. Ráadásul az államszocializmus maradványai, a rendszerváltás utáni lakásprivatizáció módja miatt vegyes tulajdonban maradt házakban is nagyobb az állami kontroll, mint az a privát szférában megszokott. Miközben a városrészt átalakító tértermelésben a nyugati kapitalizmusokhoz hasonlóan egyértelmű az állam- és a tőkeérdek összefonódása, a városrehabilitáció miatt kiszorítottak megélt tereinek átalakulási folyamata felől nézve, azt egyértelműen az állam uralja. Ezért az esettanulmány által feltárt általános mechanizmusokat figyelembe véve úgy gondolom, a jelenlegi magyarországi viszonyok között egyfajta ,államosított tértermelésről” beszélhetünk.

Jelinek (2019) különböző korszakokat elkülönítve a magyarországi városrehabilitáció történetében, a jelenlegi recentralizációs időszakban a „kettős kontroll" rendszerét írja le, amiben az egyik oldalon az önkormányzatoknak nő a központi (és az EU-) forrásoknak való kiszolgáltatottsága, míg a másik irányban erősödik a helyi társadalom feletti kontrollja. Úgy vélem, hogy az „államosított tértermelésben" megvalósuló kettősség a marginalizált társadalmi csoportok perspektívájából, egy hierarchikus rendszer végpontjáról nézve „dupla kontrollként" jelenik meg (melynek során a fentiekkel szemben ugyanaz a fél szenved el kétszeres ellenőrzést). Az önkormányzattól való függőség egyben a központi ál- 
lamtól való függőséget jelenti, a városrehabilitációban részben indirekt módon (annak szabályozása, az EU-s források elérhetőségének kontrollja révén), részben a központosított állami ellátásokkal a „segélyezés” zónájában (Castel 1993) tartva a térbeli kiszorításnak kitetteket.

A kapitalizmusban a térnek a tőke újratermelése érdekében a Lefebvre (2009) által leírt „állami termelési mód” segítségével történő kontroll alatt tartása - az ugyancsak lefebvre-i elgondolás szerint - csak autonóm decentralizációval változtatható meg. Ennek az általa elgondolt metódusa, a neoliberális kapitalizmuson belüli realitása vitatható. Úgy gondolom azonban, hogy az állam jelenlegi magyarországi centralizált modellje, az „államosított tértermelés” biztosan nem ebbe az irányba tart.

\section{Jegyzetek}

1 A kutatás más részeinek néhány eredményét lásd Nagy, Nagy (2019) e folyóirat jelen számában megjelent tanulmányában.

2 Meg kell jegyezni, hogy Castel (1993) egy negyedik övezetet is megkülönböztetett, amelynek a „segélyezés zónája” nevet adta. Ezt az övezetet a munkaképtelenség okozta munka nélküli lét és a szociális lét erős kötésének együttesével jellemezte.

3 Erre vonatkozóan néhány részlet olvasható Jelinek (2019) ebben a tematikus számban megjelent írásában.

4 Hiába kapott ez a korábban a szülőkkel együtt élni kénytelen többgyermekes fiatal család modernizált önkormányzati lakást a rehabilitáció részeként már felújított egyik házban. A salétromos, vizesedő falak, folytonos penészedés miatt folyamatos betegségeikről panaszkodva így emlékszik vissza interjúpartnerem a lakáskiutalásuk pillanatára: „Kérdezték, miért sírok. Egyrészt örültem, másrészt nagyon féltem, hogy miért pont oda. Az ember nem mert megszólalni, persze hogy elfogadta, mert akkor nem kaptam volna, de ez katasztrófa."

5 Sajnos nem állnak rendelkezésre adatok az újvárosi társadalmi-térbeli kiszorítás végállomásairól, de mivel több interjúpartner is említette a zártkerti részeket mint lehetséges célpontokat (a leromló lakótelepek mellett), feltehetően ezek lehetnek a slumosodás újratermelésének jellemző terei.

6 Azt, hogy ez a kontroll köztereken miként múködhet, lásd Sági (2019) e tematikus számban közölt tanulmányában.

\section{Köszönetnyilvánítás}

A kutatás „Az állam strukturális átalakulásaira adott intézményi és egyéni válaszok különböző földrajzi kontextusokban" c. NKFIH (OTKA) K109269 szerződésszámú projekt részét képezte, s a Nemzeti Kutatási, Fejlesztési és Innovációs Hivatal támogatásával zajlott.

Köszönöm a KRTK RKI NYUTO kutatóinak, a Család- és Gyermekjóléti Központ Újvárosi Iroda munkatársainak, illetve valamennyi interjúpartneremnek a terepmunkám során nyújtott segítségét, valamint kollégáimnak és a névtelen lektoroknak a tanulmány véglegesítéséhez nyújtott támogatását. 


\section{Irodalom}

Aczél G. (2011): A Középső-Ferencváros rehabilitációjának értékelő tanulmánya. Pécsi Tudományegyetem Pollack Mihály Műszaki Kar Breuer Marcell Doktori Iskola, Pécs

Berki M. (2015): A térbeliség trialektikája. Tér és Társadalom, 2., 3-18. https://doi.org/ 10.17649/TET. 29.2.2658

Berki M. (2017): A földrajzi lépték változó értelmezése és a cselekvőhálózat-elmélet. Földrajzi Közlemények, 3., 203-215.

Berényi B. E. (2016): Dzsentrifikációkutatás a poszt-szocialista városokban - merre tovább? Földrajzi Közlemények, 3., 204-215.

Bodnar, J., Molnar, V. (2010): Reconfiguring private and public: State, capital and new housing developments in Berlin and Budapest. Urban Studies, 2., 789-812. https://doi.org/10.1177 /0042098009351188

Boros L., Hegedűs G., Pál V. (2008): A neoliberális településpolitika konfliktusai. In: Orosz Z., Fazekas I. (szerk.): Települési Környezet. Kossuth Egyetemi Kiadó, Debrecen, 96-204.

Castel, R. (1993): A nélkülözéstől a kivetettségig - a „kiilleszkedés” pokoljárása. Esély, 3., 3-23. http:// www.esely.org/kiadvanyok/1993_3/anelkulozestol.pdf

Csanádi G., Csizmady A., Kőszeghy L., Tomay K. (2006): Belső-erzsébetvárosi rehabilitáció. Tér és Társadalom, 1., 73-92. https://doi.org/10.17649/TET.20.1.1040

Csanádi G., Csizmady A., Kőszeghy L., Tomay K. (2007): A városrehabilitáció társadalmi hatásai Budapesten. In: Enyedi Gy. (szerk.): A történelmi városközpontok átalakulásának társadalmi hatásai. MTA Társadalomkutató Központ, Budapest, 93-118. (Magyarország az ezredfordulón. Stratégiai Tanulmányok a Magyar Tudományos Akadémián.)

Csizmadia Z., Tóth P. (szerk.) (2014): A helyi társadalom és intézményrendszer Győrben. Universitas-Győr Nonprofit Kft., Győr

Czirfusz M. (2019): Munkanélküliség és az állam tértermelése Magyarországon két válságidőszakban. Tér és Társadalom, 4., 177-196. https://doi.org/10.17649/TET.33.4.3170

Czirfusz, M., Horváth, V., Jelinek, Cs., Pósfai, Zs., Szabó, L. (2015): Gentrification and Rescaling Urban Governance in Budapest-Józsefváros. Intersections, 4., 55-77. https://doi.org/10.17356/ieejsp.v1i4.104

Easton S., Lees, L., Hubbard, P., Tate, N. (2019): Measuring and mapping displacement: The problem of quantification in the battle against gentrification, Urban Studies https://doi.org/ 10.1177/0042098019851953

Egedy T. (2007): A történelmi belvárosok rehabilitációja vidéki nagyvárosainkban - Szeged és Győr. In: Enyedi Gy. (szerk.): A történelmi városközpontok átalakulásának társadalmi hatásai. MTA Társadalomkutató Központ, Budapest. 261-292. (Magyarország az ezredfordulón. Stratégiai Tanulmányok a Magyar Tudományos Akadémián)

Fekete D., Polgári I. (2016): Szociális városrehabilitáció Győr-Újváros területén. Falu, Város Régió, 2., 76-81.

Gregory, D. (1994): Geographical Imaginations. Blackwell, Oxford

Győr Megyei Jogú Város Településfejlesztési Koncepciója 2014-2030. (tervezők: Aczél G., Márton M., Szatmári Sz.) Győr, 2014.

Győr Megyei Jogú Város Középtávú Integrált Városfejlesztési Stratégiája (vezető: HHP Contact Tanácsadó Kft) Győr, 2008.

Jelinek, Cs. (2011): State-Led Gentrification and Relocation in Budapest: Vacating a House in Ferencváros. Central European University, Budapest http://www.etd.ceu.hu/2011/jelinek_csaba.pdf MA szakdolgozat

Jelinek Cs. (2019): A városrehabilitáció korszakai Magyarországon: Az állam szerepe marginális városi terek (újra)termelésében. Tér és Társadalom, 4., 17-37. https://doi.org/10.17649/TET. 33.4.3180

Kovács Z. (2005): A városrehabilitáció eredményei és korlátai Budapesten. In: Egedy T. (szerk.): Városrehabilitáció és társadalom. MTA Földrajztudományi Kutatóintézet, Budapest, 159-174. 
Közösségi Beavatkozási Terv. „Györ-Újváros szociális városrehabilitációhoz kapcsolódó társadalmi együttmüködést erősito" komplex program." TOP-6.9.1-15-GY1-2016-00001

Lees, L., Slater, T., Wyly, E. (2008): Gentrification, Routledge, Taylor \& Frances Group, New York, London Lefebvre, H. (1971): Everyday Life in the Modern World. Trans. Rabinovitch, S. Allen Lane, Harmondsworth Lefebvre, H. (1976): Reflections on the politics of space. Antipode, 2., 30-37. https://doi.org/10.1111/ j.1467-8330.1976.tb00636.x

Lefebvre, H. (1991 [1974]): The Production of Space. Trans. Nicholso-Smith, D. Blackwell, Oxford, Cambridge, MA

Lefebvre, H. (2009): State, space, world: selected essays. Ed. Brenner, N., Elden, S. and Trans. Moore, G. University of Minnesota Press, Minneapolis

Marcuse, P. (1985): To control gentrification: Anti-displacement zoning and planning for stable residential districts. Review of Law and Social Change, 13., 931-945. https://socialchangenyu.$\mathrm{com} / \mathrm{review} /$ to-control-gentrification-anti-displacement-zoning-and-planning-for-stable-residential-districts/

Megalapozó vizsgálat. Győr Megyei Jogú Város Településfejlesztési Koncepciójához és Integrált Településfejlesztési Stratégiájához (2014-2020). Szakmai vezető: Rechnitzer János, Győr Megyei Jogú Város Önkormányzata, Győr, 2014. január.

Nagy E., Timár J. (2008): A városmegújítás társadalmi következményei Európában. In: Szabó V., Orosz Z., Nagy R., Fazekas I. (szerk.): IV. Magyar Földrajzi Konferencia. Debrecen, 2008. november 14-15. Debreceni Egyetem, Debrecen, 307-313.

Nagy E., Timár J. (2012): Urban restructuring in the grip of capital and politics: Gentrification in East-Central Europe. In: Csapó, T., Balogh, A. (szerk.): Development of the Settlement Network in the Central European Countries: Past, Present, and Future. Springer Verlag, Berlin, Heidelberg, 121135. https://doi.org/10.1007/978-3-642-20314-5_9

Nagy G., Nagy E., (2019): Az állam szerepe a városi terek fogyasztásközpontú „újratermelésében”. Tér és Társadalom 4., 61-86. https://10.17649/TET.33.4.3192

Nárai M. (1998): Bérlakásokkal vagy nélkülük? Lehetőségek és igények felmérése Győrött. Tér és Társadalom, 4., 117-131. https://doi.org/10.17649/TET.12.4.491

Pálné Kovács I. (2019): A magyar önkormányzatok korlátai a helyi gazdaságfejlesztésben. Tér és Társadalom, 2., 3-19. https://doi.org/10.17649/TET.33.2.3088

Páthy Á. (2014): A társadalmi szerkezet belső területi sajátosságai. A győri városrészek és lakóövezetek társadalmi tagozódása. In: Csizmadia Z., Tóth P. (szerk.): A helyi társadalom és intézményrendszer Győrben. Univesritas-Győr Nonprofit Kft, Győr, 48-74.

Rechnitzer J., Csizmadia Z., Grosz A. (2004): A magyar városhálózat tudásalapú megújító képessége az ezredfordulón. Tér és Társadalom, 2., 117-156. https://doi.org/10.17649/TET.18.2.949

Sági M. (2019): Az állam és a közterek hanyatlása, militarizációja történelmi perspektívában. Tér és Társadalom, 4., 87-103. https://10.17649/TET.33.4.3202

Smith, N. (1996): The New Urban Frontier. Gentrification and the Revanchist City. Routledge, London, New York

Smith, N. (2002): New globalism, new urbanism: Gentrification as global urban strategy. Antipode, 3., 427-450. https://doi.org/10.1111/1467-8330.00249

Soja, E. (1996): Thirdspace. Journeys to Los Angeles and Other Real-and-Imagined Places. Blackwell, Oxford

Somogyi E., Szemző H., Tosics I. (2007): Városrehabilitáció kétszintű önkormányzati rendszerben: budapesti sikerek és problémák (1994-2006). In: Enyedi Gy. (szerk.): A történelmi városközpontok átalakulásának társadalmi hatásai. MTA Társadalomkutató Központ, Budapest. 69-92. (Magyarország az ezredfordulón. Stratégiai Tanulmányok a Magyar Tudományos Akadémián)

Terra Studió Kft. (2016): Integrált városfejlesztések értékelése. Ex-post értékelés a 2007-13-as időszakról, Projektvezető: Kukely Gy., Rácz A. Budapest

Timár J. (2006): Az agglomerálódástól a szuburbanizációig: „Tértermelés” a posztszocialista Magyarországon. In: Csapó T., Kocsis Zs. (szerk.): Agglomerációk és szuburbanizálódás Magyarországon: Településtudományi konferencia, Savaria University Press, Szombathely, 35-51.

Timár J., Nagy E. (2007): A középvárosi dzsentrifikáció és társadalmi hatásai a posztszocialista Magyarországon. In: Enyedi Gy. (szerk.): A történelmi városközpontok átalakulásának társadalmi 
hatásai. MTA Társadalomkutató Központ, Budapest, 293-317. (Magyarország az ezredfordulón. Stratégiai Tanulmányok a Magyar Tudományos Akadémián)

Tóth P., Ditrói Z. (2014): A helyi társadalom dimenziói. A lakosság lakópolgári attitűdjeinek különbségei. In Csizmadia Z., Tóth P. (szerk.): A helyi társadalom és intézményrendszer Győrben. Universitas-Győr Nonprofit Kft., Győr, 75-99.

Velkey G. (2019): A térbeli-társadalmi egyenlőtlenségek és újratermelésük az alapfokú oktatás hazai rendszerében. Tér és Társadalom 4., 104-131. thhps://doi.org/10.17649/TET.4.3179

Wacquant, L. (2011 [2007]): Lakóhely szerinti megbélyegzés a fejlett marginalitás korában. Fordulat, 13., 12-27. http://fordulat.net/pdf/13/F13_wacquant.pdf 